\title{
Overview of Some Borrowed Terms from Romance Languages in Legal Terminology in Albanian
}

\author{
Sadete Pllana ${ }^{*}$ \\ University of Prishtina "Hasan Prishtina", \\ Prishtina, Republic of Kosovo \\ Gani Pllana* \\ University of Prishtina "Hasan Prishtina”, \\ Prishtina, Republic of Kosovo
}

\section{Abstract}

Looking at the lexicon of today's Albanian, in the terminologies of different fields of knowledge, we have all the lexical wealth, consisting of two main layers: the local lexicon and the foreign lexicon, introduced through borrowings and different calques from various languages, where modern developed languages occupy an important place, especially Italian and French. One of the Albanian terminologies where this influence stands out is the legal terminology, which really has a late development, which explains the fact of its influence from developed languages, reaching to the words of general use in the field of culture and various spheres of law. It is known that foreign words spoil the language, when accepted and used unnecessarily. Foreign words should be used in those cases when they bring a new meaning, a new meaning nuance, etc., which we cannot express with the tools of Albanian language itself. Only for more concrete borrowings, such as names of newly imported tools, equipment and facilities can be spoken of as an addition to an existing vocabulary. Many borrowed words, which seemed unavoidable, have been adopted as calques, a large number of Romance borrowings today have either been replaced, or have become substituted by Albanian words. Realistically, in legal terminology there is not only a relatively large number of borrowings, but also a range of lexical overlaps with Romance languages.

Keywords: borrowed terms, Romance languages, legal terminology, and Albanian language

\section{Introduction}

Throughout its history, Albanian has been in contact with various languages of the Balkan Peninsula. 
Speaking especially about the influence of Italian terminology on legal terminology in the Albanian language, we should mention the predecessor of the Italian language, i.e., the Latin language, viewed from the point of view of the impact on Albanian terminologies as a whole. The influence of Latin on the Albanian language was exercised for a relatively long time of several centuries, as a state language, as a language of economic and trade relations, as a language of culture, where Latin elements in the lexicon occupy the first place among Albanian borrowings by number and the extent of their use. Albanian Latinisms are presented in forms that belong to different time layers (Domi, 1988:179).

Latinisms belong to the general lexical layer and partly to the early Albanian terminologies. Latinisms in legal terms have entered, let say as Italianized Latinisms through Italian. Latin borrowings of Albanian are embedded in the Albanian lexicon, especially in the general lexicon, apparently at a very early time, so much so that it becomes necessary for Latin borrowings, at least for early times, to be viewed not as borrowings, but rather as "Early Latin words" (Çabej, 1976:56). Italy's linguistic influence in Albania continued unabated even after the end of Roman rule and only with the Ottoman conquest of the country the pace of this influence slow down somewhat. As in Roman times, even during the middle ages the relations between Italy and Albania were mainly political, religious, trade/economic and cultural.

When it comes to the Italian influence on the Albanian language, we must be clear from a historical point of view. The Latin element must be distinguished from the Italian element of Albanian, to separate where the first ends and where the influence of the second begins. This is one of the fundamental problems of the linguistic history of Albanian. Without being able to make a definite distinction, it can be said that Italian was formed from Latin in the seventh century AD. This is the time limit between these two languages, a goal that would be taken into account in the study of Albanian novels.

The share of Latin borrowings in Albanian, in the general lexicon, is so large that the Albanian language has often been described as a "mixed semi-Romance language", where G. Mayer wrote: "It is beyond any doubt that the Albanian language has escaped for a hair the complete Romanization, just like the Celtic language in France. It came out of this period with severe damage to sounds, vocabulary and grammatical forms". (Helmut, 1988:329).

In the following we will present some borrowings in the general lexicon of Albanian, especially displayed as a book lexicon, but used in the fields of legal terminology, although not as direct terms of it:

\section{In general language:}

abstenim-i (lat. abstinentia- përmbajtje --abstain, not participating in a voting ), abuzim-i (lat. abusus- tepri, shpërdorim-- excess, abuse, misuse; 
adaptim-i (lat. adaptatio- përshtatje--adaptation);

aksesor-i (lat. accessorium-shtojcë; complementary or second-hand part attached to the main, appendix);

dedikim-i (lat.dedicatio-kushtim; përkushtim, të kushtuarit-- dedication, devotion). edukim-i (lat. educatio-edukatë; të edukuarit--education).

evoluim-i (lat. evolutio-zhvillim; -- evolution, gradual change and development of something).

inaugurim-i (lat. inaugurare-shuguroj; inaugurate; inauguration, official ceremony on the occasion of starting work in an object of economic or social importance).

koment-i (lat. commentarium-shënime, diary; explanation and evaluation of a social or political event).

konstante/tja (lat. constants-i qëndrueshëm; -- stable; constant size).

minus-i (lat. minus-pa, i vogël; --sign (-) placed between two numbers or two quantities to indicate the arithmetic operation of the subtraction).

rezidencë- $a$ (lat. residentia-vendqëndrim, vendbanim;--the place or building where the government, the head of state or a senior official permanently resides, the seat). spektator-i (lat. spectator-shikues;-- one who watches an artistic, sports, etc. show.).

\section{Historical conditions and geographical circumstances - linguistic contacts}

The presence of borrowings in a language is clear evidence of linguistic contacts established on the basis of the geographical circumstances and historical conditions of the people whose languages have these borrowings. The process of language borrowing is a common phenomenon with a more or less universal character, therefore a large number of works have been devoted to this problem where definitions have been given and classifications of borrowings from different perspectives have been made. (Thomai, 1984:192).

Before we start dealing with borrowings in the legal lexicon we are stopping with the treatment of borrowings in various linguistic and terminological studies.

There are two types of borrowings:

imported borrowing, when the borrowing is so similar to the model that the local speaker can accept as it own, and

substituted borrowing, when the speaker incorrectly reproduces the foreign model, replacing it in a similar form by his/her language. 


\section{The main factors that have determined the entry of borrowings from Italian and French into Albanian legal terminology}

Even today, there is a determined struggle to make foreign words superseded, in those cases when we have Albanian and more popular words for them, which express completely the same meaning. The word is born and invented it changes and develops, but, at the end it may even disappear altogether. Words disappear with objects or notions of time, many others are replaced by borrowed words from other languages.

It is known that no language is isolated and protected from external intrusions.

Terms derived from Italian and French in Albanian, in legal terminology, constitute a relatively large part of the entire lexicon borrowed from these two languages.

The main factors that determined these relations and borrowings were the important changes that took place in the economic-social, political, ideological and cultural life of the Albanian people during the National Renaissance, and after the declaration of independence of the Albanian state in 1912. In Albania, the military administration of Korça with its surroundings from 1917 to 1921, the Lyceum of Korça, where classes were held in French, from 1917 until the occupation of Albania by Italian fascist forces, the presence of many Italian and French companies that used the richness of the Albanian land, changed the structure of the population by putting it in living connection with the life and culture expressed in Italian and French languages. This situation was largely reflected in the Albanian lexicon, where borrowings from Italian took on greater numbers than from French. Such a phenomenon is reasonable given the neighborhood of the Albanian people with Italy.

\section{Work on replacing some foreign terms with words from the Albanian lexicon}

Borrowed terms are of two types: foreign international terms and non-international foreign terms.

For the needs of completing the basic terminology of legal terminology, two types of borrowings can be accepted:

Internal or intra-linguistic borrowings that come within the language from terminologies of other fields;

External borrowings, which come from foreign language terminologies.

Here we will review the part of borrowings, which in legal terminology come from the Italian and French language terminologies.

In order to highlight these features, which are observed in both languages, we can bring a series of examples, which highlight the degree of borrowings of the legal lexicon in the Albanian language. For this we are presenting examples from the opposite, giving the first Albanian language and the second-Italian, as well as French: 


\begin{tabular}{|c|c|}
\hline In Albanian & In Italian (Derived from or through Italian) \\
\hline akaparim-i & accaparramento \\
\hline akaparoj & accaparrare \\
\hline akaparues-i & accaparratore \\
\hline arkivist-i & archivista \\
\hline arrest-i & arresto \\
\hline arrest-i & arresto \\
\hline arrestim-i & arresto \\
\hline arroganc/ë-a & arroganca \\
\hline arrogant-i & arrogante \\
\hline banal-e & banale \\
\hline bandë-a & banda \\
\hline bandit- $i$ & bandito \\
\hline banditiz/ëm-mi & banditismo \\
\hline bankrotim-i & bancarotta \\
\hline baronesh/ë-a & baronessa \\
\hline baron-i & barone \\
\hline barrikad/ë-a & barricata \\
\hline degjeneroj & degenarare \\
\hline demarkacion-i & demarcazione \\
\hline dispozicion-i & disposizione \\
\hline finac/ë- $a$ & finanza \\
\hline financ/oj & finanziare \\
\hline financier-i & finanziere \\
\hline indipenden/ë- $a$ & indipendenza \\
\hline itinerar-i & itinerario \\
\hline karrieriz/ëm-mi & carrierismo \\
\hline kolegjial-e & collegio \\
\hline komisionar-i & commissionario \\
\hline
\end{tabular}




$\begin{array}{ll}\text { kontribut-i } & \text { contributo } \\ \text { kurtuazi-a } & \text { courtoise } \\ \text { padron-i } & \text { padrone } \\ \text { parull/ë-a } & \text { parola } \\ \text { repart-i } & \text { reparto } \\ \text { revist/ë-a } & \text { revista } \\ \text { skadim-i } & \text { scadenza } \\ \text { sked/ë-a } & \text { scheda } \\ \text { skedim-i } & \text { schedatura } \\ \text { skedoj } & \text { schedare } \\ \text { sovran-i } & \text { sovrano } \\ \text { sovranitet-i } & \text { sovranita } \\ \text { spiun-i } & \text { spionare } \\ \text { sportle-i } & \text { sportello } \\ \text { valut/ë-a } & \text { valuta } \\ \text { valutor-e } & \text { valutario } \\ \text { virtuoz-i } & \text { virtuosita } \\ \text { xhiroj } & \text { girare } \\ \text { xhiro-ja } & \text { Ironte } \\ \text { xhirues-i } & \text { iro }\end{array}$

In Albanian

In French (Derived from or through Italian)

atashe-u

attaché

balotazh-i

ballottage

realizim- $i$

realisation

rekrutim-i

recrutement

rekrutoj

recruter

rent/ë-a

rente

rutin/ë- $a$

routine

sabotim-i

sabotage 


$\begin{array}{ll}\text { sabotues-e } & \text { saboteur } \\ \text { sadist-i } & \text { sadique } \\ \text { sadizëm-mi } & \text { sadisme } \\ \text { seanc/ë-a } & \text { seance } \\ \text { sondazh-i } & \text { sondage } \\ \text { trezor-i } & \text { tresor } \\ \text { asamble-ja } & \text { assemble } \\ \text { azhirim-i } & \text { ajournement } \\ \text { azhurnoj } & \text { ajourner } \\ \text { broshur/ë-a } & \text { broschure } \\ \text { deplasim-i } & \text { deplacement } \\ \text { debat-i } & \text { débet } \\ \text { debllokim-i } & \text { deblocage } \\ \text { debllokoj } & \text { debloquer } \\ \text { debutim-i } & \text { debut } \\ \text { debutoj } & \text { debuter } \\ \text { debutues-i } & \text { debutant } \\ \text { eksploatim-i } & \text { exploitation } \\ \text { eksploatoj } & \text { exploiter } \\ \text { eksploatues-i } & \text { exploiteur } \\ \text { demarsh-i } & \text { démarche } \\ \text { demaskim-i } & \text { demasquer } \\ \text { departament-i } & \text { départment } \\ \text { deshifrim-i } & \text { dechiffrement } \\ \text { deshifrues-i } & \text { dechifftreur } \\ \text { detashment-i } & \text { detachement } \\ \text { kurtuazi-a } & \text { courtoisie } \\ \text { liberaliz/ëm-mi } & \text { liberatismo } \\ \text { liberalizoj } & \\ \text { liberaliser } \\ \end{array}$




$\begin{array}{ll}\text { marionet/ë-a } & \text { marionette } \\ \text { financ/ë- } a & \text { finance } \\ \text { finansier-e } & \text { financier } \\ \text { financoj } & \text { financer } \\ \text { fines/ë-a } & \text { finesse } \\ \text { garanci-a } & \text { garantie } \\ \text { grup-i } & \text { groupe } \\ \text { homazh-i } & \text { homage } \\ \text { indisponibël } & \text { indisponible } \\ \text { kamuflim-i } & \text { camouflage } \\ \text { kontroll-i } & \text { contôler } \\ \text { kontrollor-i } & \text { contrôleur } \\ \text { massakrim-i } & \text { massacre } \\ \text { nonshalant-e } & \text { nonchalan }\end{array}$

Legal terminology, as terminology of a field with a wide scope in practice, is related to the daily life of teachers in high schools and professors in Albanian universities, people with problems of the time they have, should be helped in communication, mainly specialists for conversations and precise actions.

It can be said that legal terminology is consolidated to some extent, but work should continue to supplement and revise dictionaries for narrow fields of knowledge to improve the carried shortcomings, but especially to solve the problems of the time in this terminology.

\section{Conclusion}

The influence of Latin and Romance languages on Albanian has been great, but sometimes their traces have been overestimated.

Linguistic facts show that Albanian, for one reason or another, for one or the other status, has taken many words from Romance languages.

In reality, Albanian resisted the strong influence of Latin and Romance languages and was not assimilated by them.

Borrowed Romance words of Albanian are phonologically adapted according to the principles and phonological habits of Albanian.

Romance phonemes, of Italian and French, are changed and modified in our language by pronunciation and spelling. Most Italian borrowings have penetrated into Albanian 
directly from the spoken language, while French borrowings have penetrated more on the basis of writings and written orthographic form.

\section{References}

[1] Bejta, M. (1985), "Fjalor frëngjisht-shqip", ETMM, Prishtinë, 1985.

[2] Çabej, E. (1976), "Studime gjuhësore III”, RILINDJA, Prishtinë, 1976, p. 56-58.

[3] Çabej. N. (1980), "Nga historia e zhvillimit të shkencës shqiptare", Shtëpia botuese "8 Nëntori", Tiranë, 1980.

[4] Domi, M. (1988), "Probleme të historisë së formimit të gjuhës shqipe" në Konferenca kombëtare për formimin e popullit shqiptar të gjuhës dhe të kulturës së saj, (Tiranë, 2-5 korrik 1982), Tiranë, 1988, f. 179.

[5] Duro, A. (2009):"Termi dhe fjala në gjuhën shqipe (në rrafshin e formës dhe të përmbajtjes)", QSA Shtëpia botuese "Fan Noli”, Tiranë, 2009.

[6] Duro, A. (2012): "Studime gjuhësore", QSA Botimet Albanologjike, Tiranë, 2012.

[7] Helmut, Sh. (1988), "Çështja e zhillimit të leksikut të shqipes së sotme" në Konferenca kombëtare për formimin e popullit shqiptar të gjuhës dhe të kulturës së saj, (Tiranë, 2-5 korrik 1982), Tiranë, 1988, p. 329.

[8] Lacaj, H. \&Fishta, F. (1980), "Fjalor latinisht-shqip”, Rilindja, Prishtinë, 1980.

[9] Thomai, J. (1984): “Leksikologjia e gjuhës shqipe”, Tiranë, 1984, p. 191-194.

[10] Voci, H. (1980), "Fjalor italisht-shqip" Shtëpia botuese "8 Nëntori", Tiranë, 1980.

[11] Bejta, M. (1985), "Fjalor frëngjisht-shqip- French-Albanian dictionary", ETMM, Prishtinë, 1985.

[12] Çabej, E. (1976), "Studime gjuhësore III- Linguistic studies III", RILINDJA, Prishtinë, 1976, p. 56-58. (In Albanian).

[13] Çabej. N. (1980), "Nga historia e zhvillimit të shkencës shqiptare-From the history of the development of Albanian science ", Shtëpia botuese Publishing House "8 Nëntori", Tiranë, 1980. (In Albanian).

[14] Domi, M. (1988), "Probleme të historisë së formimit të gjuhës shqipeProblems of the history of the formation of the Albanian language" në Konferenca kombëtare për formimin e popullit shqiptar të gjuhës dhe të kulturës së saj - in the National Conference on the formation of the Albanian people of its language and culture,, (Tiranë, 2-5 July 1982), Tiranë, 1988, p. 179. (In Albanian). 
[15] Duro, A. (2009):"Termi dhe fjala në gjuhën shqipe (në rrafshin e formës dhe të përmbajtjes)- Term and word in Albanian language (in terms of form and content)", QSA Shtëpia botuese - Publishing House "Fan Noli", Tiranë, 2009 (In Albanian).

[16] Duro, A. (2012): "Studime gjuhësore - Linguistic Studies ", QSA Botimet Albanologjike - QSA Albanological Publications, Tiranë, 2012. (In Albanian).

[17] Helmut, Sh. (1988), "Çështja e zhillimit të leksikut të shqipes së sotme-The issue of developing the lexicon of today's Albanian" në Konferenca kombëtare për formimin e popullit shqiptar të gjuhës dhe të kulturës së saj - in the National Conference on the formation of the Albanian people of its language and culture,, (Tiranë, 2-5 July 1982), Tiranë, 1988, p. 329. (In Albanian).

[18] Lacaj, H. \&Fishta, F. (1980), "Fjalor latinisht-shqip", Rilindja, Prishtinë, 1980.

[19] Thomai, J. (1984): “Leksikologjia e gjuhës shqipe - Lexicology of the Albanian language", Tiranë, 1984, p. 191-194. (In Albanian).

[20] Voci, H. (1980), "Fjalor italisht-shqip-Italian-Albanian Dictionary" Shtëpia botuese - Publishing House "8 Nëntori", Tiranë, 1980. 